\title{
Efektivitas Daun Seledri terhadap Penurunan Tekanan Darah pada Penderita Hipertensi di Puskesmas Pembantu Berngam Kota Binjai Tahun 2021
}

\author{
Irma Handayani ${ }^{1, *}$, Sri Wahyuni ${ }^{2}$ \\ ${ }^{1}$ Sekolah Tinggi Ilmu Kesehatan Sehat Medan, Jln. Gaperta Ujung, Tj. Gusta, Kec. Medan Helvetia, Kota Medan, 20125, Indonesia \\ ${ }^{1}$ handay1502@ gmail.com*; ${ }^{2}$ wahyuni0130@gmail.com \\ * corresponding author
}

ARTICLE INFO

Article history

17-08-2021

29-08-2021

19-09-2021

Keywords

Giving celery leaves

Blood pressure

Hypertensive patient

\section{ABSTRACT}

Hypertension is an increase in blood pressure by providing further symptoms to a target organ including stroke (in the brain), coronary heart disease (in the heart blood vessels) and right ventricular hypertrophy or left ventricular hypertrophy (for the heart muscle). The target organ in the brain is in the form of stroke, hypertension is the main cause of stroke which brings high mortality. Management of hypertension can be managed with non-pharmacological measures such as giving celery leaves. The purpose of the study was to analyze the effectiveness of giving celery leaves to reduce blood pressure in patients with hypertension at the Pembantu Berngam Health Center, Binjai City in 2021. This type of research was a quasi-experimental design with a pretest-posttest control group design with one type of treatment. This study uses an intervention that is giving celery leaves by boiling. The intervention was given once in the morning by giving 100 grams of boiled celery for 5 days. The number of samples of 30 respondents with 15 people as the control group and 15 people in the intervention group were taken by accidental sampling. The results of the average blood pressure before and after giving boiled celery in the treatment group with systolic blood pressure p-value is 0.00 , diastolic blood pressure pvalue is 0.00 . The results of statistical tests using the Wilcoxon test for both systolic and distolic pressure in the group not given celery were tilapia p-value $>0.05$, namely systolic pressure $p$-value 0.07 and distolic p-value 0.05 . The results of the Mann Whitney U statistical test analysis for systolic and distolic blood pressure obtained a p-value of 0.047 and a diastolic pressure $\mathrm{p}$-value of 0.01 or a $\mathrm{p}$-value $<0.05$, which means that there is an effectiveness of giving celery leaves in reducing blood pressure in hypertensive patients at the Berngam Binjai sub-health center. It is hoped that health workers will be able to apply complementary therapy to patients with hypertension in maintaining and lowering blood pressure.

\section{Pendahuluan}

Hipertensi merupakan salah satu penyakit tidak menular bagian kardiovaskuler penyebab utama kematian, dan cukup sulit untuk dikendalikan. Dewas ini prevalensi penyakit cukup tinggi pada masyarakat baik secara global maupun nasional [1].

Hipertensi di Amerika Serikat dari tiga orang dewasa mempunyai hipertensi yang menjadi sumber penyebab pertama dan ketiga kematian, lebih dari 348.000 meninggal sehubungan dengan hipertensi, serta hipertensi memberikan kontribusi terbesar terhadap kematian sebanyak 326.000 di tahun 2006 [1]. Menurut data Riset Kesehatan Dasar 2018 ditemukan prevalensi penduduk Indonesia berusia $\geq 18$ tahun yang menderita hipertensi berdasarkan diagnosis dokter sebanyak $8,4 \%$, berdasarkan diagnosis atau minum obat hipertensi sebanyak $8,8 \%$, sedangkan berdasarkan hasil pengukuran sebanyak $34,1 \%$. Data prevalensi penderita hipertensi pada provinsi Sumatera 
Utara penduduk yang berusia $\geq 18$ tahun sebanyak 22,9\% [2]. Profil Kesehatan Puskesmas Pembantu Berngam Binjai Provinsi Sumatera Utara tahun 2019 bahwa penyakit hipertensi termasuk urutan ke 5 dari daftar penyakit yang ada di wilayah kerja Puskesmas tersebut.Hipertensi merupakan suatu kondisi medis yang kronis dimana tekanan darah meningkat dari batas normal yaitu tekanan darah sistolik $120 \mathrm{mmHg}$ dan tekanan darah diastolik $80 \mathrm{mmHg}$ [3]. Hipertensi juga disebut "silent killer" karena tidak mempunyai atau disadari akan keberadaannya. Karena itu, diperlukan pemeriksaan tekanan darah secara teratur [1]. Salah satu pengobatan secara non farmakologis yang dapat menurunkan tekanan darah tinggia dalah seledri [4]. Daun seledri banyak mengandung apiin, suatu senyawa yang bersifat diuretic dan diduga mampu melebarkan pembuluh darah.Seledri telah banyak digunakan di masyarakat dan telah banyak dilakukan penelitian mengenai efek farmakologinya dan telah terbukti mampu menurunkan tekanan darah tinggi [5].

\section{Metode}

Jenis penelitian ini adalah pendekatan analitik kuantitatif dengan desain ekperimen semu (quasi eksperimen) dengan rancangan pretest-posttest control group design dengan satu macam perlakuan. Penelitian ini menggunakan intervensi yaitu pemberian daun seledri dengan cara direbus. Pemberian intervensi dilakukan 1 kali pada waktu pagi dengan memberikan rebusan seledri sebanyak 100 gram selama 5 hari.Populasi dalam penelitian ini adalah seluruh penderita hipertensi di wilayah kerja Puskesmas Pembantu Berngam Kota Binjai tahun 2021. Sampel minimal 28 responden, untuk mengatasi adanya kemungkinan sampel drop out, maka dilakukan penambahan jumlah sampel sebanyak $10 \%$ sehingga total sampel pada penelitian ini sebanyak 30 responden. Teknik sampling yang digunakana dalah aksidental sampling yaitu teknik penentuan sampel berdasarkan kebetulan, yaitu siapa saja yang secara kebetulan bertemu dengan peneliti dapat digunakan sebagai sampel.

\section{Hasil}

\section{Hasil Univariat}

Tabel 4.1. Karakteristik Responden di Wilayah Kerja Puskesmas Pembantu Berngam Tahun 2021

\begin{tabular}{|c|c|c|c|c|c|}
\hline \multirow{2}{*}{ No } & \multirow{2}{*}{ Data Demografi } & \multicolumn{2}{|c|}{ Kelompok Perlakuan } & \multicolumn{2}{|c|}{ Kelompok Kontrol } \\
\hline & & $\mathbf{f}$ & $\%$ & $\mathbf{f}$ & $\%$ \\
\hline \multirow[t]{4}{*}{1} & Umur & & & & \\
\hline & 40-50 tahun & 0 & 0,0 & 3 & 20,0 \\
\hline & 51-60 tahun & 9 & 60,0 & 5 & 33,3 \\
\hline & $>60$ tahun & 6 & 40,0 & 7 & 46,7 \\
\hline \multirow[t]{3}{*}{2} & Jenis Kelamin & & & & \\
\hline & Laki-laki & 3 & 20,0 & 4 & 26,7 \\
\hline & Perempuan & 12 & 80,0 & 11 & 73,3 \\
\hline \multirow[t]{4}{*}{3} & Pendidikan & & & & \\
\hline & Tidak Sekolah & 2 & 13,4 & 9 & 60,0 \\
\hline & Tamat SD & 8 & 53,3 & 4 & 26,7 \\
\hline & Tamat SMP & 5 & 33,3 & 2 & 13,3 \\
\hline \multirow[t]{5}{*}{4} & Pekerjaan & & & & \\
\hline & IRT & 11 & 73,3 & 11 & 73,3 \\
\hline & Wiraswasta & 4 & 26,7 & 3 & 20,0 \\
\hline & Pensiunan & 0 & 0,0 & 1 & 6,7 \\
\hline & Jumlah & 15 & 100 & 15 & 100 \\
\hline
\end{tabular}

Hasil pada tabel 4.1 menunjukkan bahwa pada kelompok perlakuan sebagian besar responden penelitian adalah kelompok usia 51-60 tahun (60\%), dan usia >60 tahun (40\%). Berdasarkan jenis kelamin sebagian besar responden adalah perempuan sebanyak 12 orang $(80 \%)$ dan laki-laki sebanyak 3 orang (20\%). Tingkat pendidikan responden sebagian besar adalah tamat SD sebanyak 8 orang $(53,3 \%)$. Berdasarkan pekerjaan sebagian besar responden adalah Ibu rumah tangga 11 orang $(73,3 \%)$. 
Tabel 4.2. Distribusi Rata-Rata Tekanan Darah Systole dan Diastole Sebelum diberikan Seledri Pada Penderita Hipertensi

\begin{tabular}{llll}
\hline Tekanan darah & Mean $($ Pre-test $)$ & Standar Deviasi & Min - Max \\
\hline Sistole $(\mathrm{mmHg})$ & 156,00 & 9,103 & $140-170$ \\
\hline Diastole $(\mathrm{mmHg})$ & 99,33 & 2,582 & $90-100$ \\
\hline
\end{tabular}

Berdasarkan hasil pengukuran terhadap responden yang ditampilkan dalam tabel diatas, diketahui bahwa rata-rata tekanan sistole responden sebelum diberikan seledri yaitu $156,00 \mathrm{mmHg}$ dengan nilai minimum adalah $140 \mathrm{mmHg}$, maximum $170 \mathrm{mmHg}$, dan standar deviasi 9,103 mmHg. Sedangkan, rata-rata tekanan diastole responden sebelum diberikan perlakuan yaitu $99,33 \mathrm{mmHg}$ dan nilai minimum $90 \mathrm{mmHg}$, maximum $100 \mathrm{mmHg}$, dengan standar deviasi 2,582 $\mathrm{mmHg}$.

Tabel 4.3. Distribusi Rata-Rata Tekanan Darah Systole dan Diastole Sesudah diberikan Seledri Pada Penderita Hipertensi

\begin{tabular}{llll}
\hline Tekanan darah & Mean (Post-test) & Standar Deviasi & Min - Max \\
\hline Sistole $(\mathrm{mmHg})$ & 144,67 & 9,155 & $130-160$ \\
\hline Diastole $(\mathrm{mmHg})$ & 90,67 & 2,582 & $90-100$ \\
\hline
\end{tabular}

Berdasarkan hasil pengukuran terhadap responden yang ditampilkan dalam tabel 4.3 diatas, diketahui bahwa rata-rata tekanan sistole responden sesudah diberikan seledri yaitu $144,67 \mathrm{mmHg}$ dengan nilai minimum adalah $130 \mathrm{mmHg}$, maximum $160 \mathrm{mmHg}$, dan standar deviasi 9,155 mmHg. Sedangkan, rata-rata tekanan diastole responden sesudah diberikan perlakuan yaitu $90,67 \mathrm{mmHg}$ dan nilai minimum $90 \mathrm{mmHg}$, maximum $100 \mathrm{mmHg}$, dengan standar deviasi 2,582 $\mathrm{mmHg}$.

\section{Analisa Bivariat}

a. Uji Normalitas

Uji normalitas dilakukan untuk mengetahui data terdistribusi normal atau tidak dan menentukan uji statistik yang akan digunakan.

Tabel 4.4. Uji Normalitas Data dengan Shapiro-Wilk

\begin{tabular}{clll}
\hline Kelompok & Tekanan darah & p-value & Keterangan \\
\hline \multirow{2}{*}{ Perlakuan } & Sistole Awal & 0,050 & Tidak Normal \\
& Sistole Akhir & 0,082 & Normal \\
\hline \multirow{2}{*}{ Perlakuan } & Diastole Awal & 0,000 & Tidak Normal \\
& Diastole Akhir & 0,000 & Tidak Normal \\
\hline \multirow{2}{*}{ Kontrol } & Sistole Awal & 0,008 & Tidak Normal \\
& Sistole Akhir & 0,018 & Tidak Normal \\
\hline \multirow{2}{*}{ Kontrol } & Diastole Awal & 0,000 & Tidak Normal \\
& Diastole Akhir & 0,000 & Tidak Normal \\
\hline
\end{tabular}

Dari tabel 4.4 dimana uji normalitas menggunakan uji Shapiro-Wilk didapatkan nilai $\rho$ value baik pada tekanan darah sistole awal dan akhir maupun diastole awal dan akhir rata-rata menunjukkan nilai $\rho<0,05$. Hal ini berarti bahwa data terdistribusi tidak normal, maka uji statistik dapat dilanjutkan dengan uji alternatif yaitu dengan uji wilcoxon untuk mengetahui perbedaan tekanan darah sebelum dan sesudah dilakukan pemberian rebusan air seledri pada kelompok perlakuan dan kontrol. 
Tabel 4.5. Rata-rata Tekanan Darah Sebelum dan Sesudah Dilakukan Pemberian Rebusan Air Seledri Pada Kelompok Perlakuan

\begin{tabular}{llllll}
\hline Tekanan darah & Mean (Pre) \pm SD & Mean (Post) \pm SD & $\begin{array}{l}\text { Selisih Mean } \pm \\
\text { SD }\end{array}$ & Z-hitung & $p$-value \\
\hline Sistole $(\mathrm{mmHg})$ & $156,00 \pm 9,103$ & $144,67 \pm 9,155$ & $11,33 \pm 5,164$ & $-3,494$ & 0,000 \\
\hline $\begin{array}{l}\text { Diastole } \\
(\mathrm{mmHg})\end{array}$ & $99,33 \pm 2,582$ & $90,67 \pm 2,582$ & $8,67 \pm 3,519$ & $-3,606$ & 0,000 \\
\hline
\end{tabular}

Hasil pada tabel 4.5 menunjukan bahwa baik tekanan darah sistole maupun diastole terjadi penurunan secara bermakna setelah diberikan air rebusan seledri selama 5 hari berturut-turut. Ratarata penurunan tekanan darah sistole 11,33 $\mathrm{mmHg}$ dan Diastole 8,67 mmHg.

Tabel 4.6. Hasil Uji Statistik Tekanan Darah (mmHg) Kelompok Perlakuan dan Kontrol

\begin{tabular}{|c|c|c|c|c|}
\hline Kelompok & Mean \pm SD & Selisih Mean \pm SD & Z-hitung & p-value \\
\hline Perlakuan & $144,67 \pm 9,155$ & & & \\
\hline Kontrol & $151,33 \pm 9,155$ & $6,67 \pm 3,433$ & $-1,989$ & 0,047 \\
\hline Perlakuan & $90,67 \pm 2,582$ & $4,00 \pm 1,491$ & $-2,436$ & 0,015 \\
\hline Kontrol & $94,67 \pm 5,164$ & & & \\
\hline
\end{tabular}

Hasil pada tabel 4.6 menunjukkan bahwa ada perbedaan yang bermakna penurunan tekanan darah baik pada tekanan sistole maupun diastole antara kelompok perlakuan dengan kelompok kontrol. Hasil ini dapat disimpulkan bahwa pada kelompok yang diberikan air rebusan seledri lebih baik dalam menurunkan tekanan darah baik pada tekanan sistole maupun diastole. Hasil uji statistik (Mann Whitney $U$ ) untuk tekanan darah sistole diperoleh p-value 0,047 dan untuk tekanan darah diastole diperoleh $\mathrm{p}$-value 0,015 atau nilai $\mathrm{p}<\alpha(0.05)$ yang artinya bahwa terdapat perbedaan yang bermakna tekanan darah sistolik dan diastolik pada kelompok perlakuan dan kelompok kontrol di Wilayah Kerja Puskesmas Pembantu Berngam Tahun 2019. Bila dilihat besarnya perbedaan penurunan tekanan darah sistole antara kelompok perlakuan dan kelompok kontrol yaitu 6,67 mmHg. Begitu juga pada tekanan diastole antara kelompok perlakuan dan kelompok kontrol terdapat perbedaan sebesar 4,00 $\mathrm{mmHg}$. Sehingga dapat diasumsikan bahwa kelompok perlakuan (yang diberikan seledri) terjadi penurunan tekanan sistole dan diastole yang lebih baik dibandingkan kelompok kontrol (yang tidak diberikan seledri). Sehingga dapat disimpulkan bahwa terdapat pengaruh yang signifikan pemberian daun seledri terhadap penurunan tekanan darah pada penderita hipertensi di wilayah kerja Puskesmas Pembantu Berngam tahun 2021.

\section{Pembahasan}

\section{Perubahan Tekanan Darah sebelum dan sesudah diberikan terapi rebusan daun Seledri Pada penderita Hipertensi}

Berdasarkan hasil pengukuran terhadap responden diketahui bahwa rata-rata tekanan sistole responden sebelum diberikan seledri yaitu $156,00 \mathrm{mmHg}$ sedangkan rata-rata tekanan sistole sesudah diberikan seledri menurun menjadi $144,67 \mathrm{mmHg}$. Rata-rata tekanan diastole responden sebelum diberikan perlakuan yaitu $99,33 \mathrm{mmHg}$ dan rata-rata tekanan diastole sesudah diberikan perlakuan menurut menjadi $90,67 \mathrm{mmHg}$.

Berdasarkan hasil tersebut menunjukan bahwa baik tekanan darah sistole maupun diastole terjadi penurunan secara bermakna setelah diberikan air rebusan seledri selama 5 hari berturut-turut. Rata- 
rata penurunan tekanan darah sistole 11,33 $\mathrm{mmHg}$ dan Diastole $8,67 \mathrm{mmHg}$. Berdasarkan hasil uji statistik (Uji wilcoxon) didapatkan baik tekanan sistole maupun diastole diperoleh nilai p-value 0,000 atau $\mathrm{p}<0,05$ yang berarti ada perbedaan yang signifikan tekanan darah sebelum dan sesudah dilakukan pemberian rebusan air seledri pada kelompok perlakuan. Sehingga disimpulkan bahwa ada pengaruh pemberian air rebusan seledri terhadap penurunan tekanan darah pada penderita hipertensi.

Hal ini menunjukkan bahwa setelah pemberian air rebusan seledri dua kali sehari selama lima hari sebanyak 100 gram yang diberikan tiap pagi dapat menyebabkan tekanan darah sebagian besar responden mengalami penurunan. Meskipun ada juga responden yang tekanan darahnya tetap setelah pemberian air rebusan seledri, ini terjadi kemungkinan di sebabkan oleh umur responden yang sudah tua, yang di mana elastisitas dari pembuluh darah yang sudah tua mengalami kekakuan dan tidak elastisitas lagi sehingga pemberian air daun seledri kurang bekerja maksimal.

Menurut penelitian Asmawati [4] yang berjudul Efektivitas Rebusan Seledri Dalam Menurunkan Tekanan Darah Pada Lansia Penderita Hipertensi. Hasil penelitian menunjukkan bahwa rata-rata tekanan darah sistole dan diastole responden berangsur-angsur dapat berkurang selama 1 minggu dengan meminum rebusan seledri. Dimana rata-rata tekanan sistole sebelum perlakuan yaitu 166,33 mmHg. Sedangkan, rata-rata tekanan sistole setelah diberikan perlakuan selama 1 minggu yaitu 146,28 mmHg. Rata-rata tekanan diastole sebelum perlakuan yaitu 98,17 mmHg. Sedangkan, untuk rata-rata tekanan diastole setelah diberikan perlakuan selama 1 minggu yaitu 84,50 $\mathrm{mmHg}$. Hasil uji statistik didapatkan nilai p-value 0,000 dan $\alpha$ adalah 0,05 sebagai derajat kepercayaan pada penelitian ini. Maka dapat disimpulkan bahwa adanya pengaruh yang signifikan antara sebelum dan sesudah minum rebusan seledri terhadap penurunan tekanan darah.

Menurut penelitian Lazdia [6] yang berjudul pengaruh rebusan daun seledri untuk menurunkan tekanan darah pada penderita hipertensi yang mengatkan bahwa rerata tekanan darah sitolik sesudah

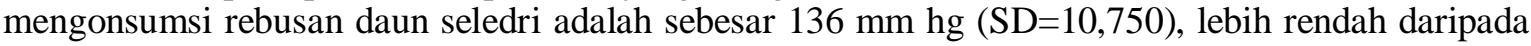
rerata tekanan darah sistolik sebelum mengonsumsi rebusan daun seledri yakni sebesar $142 \mathrm{~mm}$ hg $(\mathrm{SD}=13,984)(\mathrm{p}>0,05)$. Rata- rata tekanan darah diastolik sesudah mengonsumsi rebusan daun seledri adalah sebesar $87 \mathrm{~mm} \mathrm{hg}(\mathrm{SD}=4,830)$ lebih rendah dari pada tekanan darah diastolik sebelum mengonsumsi daun seledri sebesar $94 \mathrm{~mm} \mathrm{hg}(\mathrm{SD}=9,661)(\mathrm{p}<0,05)$.

Seledri merupakan tanaman herbal yang sangat rendah kalori. Daun seledri hanya berisi 16 kalori per 100 gram dan mengandung serat non larut, yang bila dikombinasikan dapat menurunkan berat dan kadar kolesterol dalam darah, sumber yang kaya antioksidan flavonoid seperti zea xanthin, lutein, dan beta karoten yang berfungsi sebagai pelindung tubuh, meningkatkan imunitas tubuh dan pencegahan kanker. Seledri merupakan sumber vitamin A yang baik. Vitamin A dan beta karoten adalah antioksidan flavonoid alami yang dibutuhkan untuk menjaga kulit,mata,dan selaput lendir agar selalu sehat.

\section{Efektivitas Rebusan Daun Seledri Untuk Menurunkan Tekanan Darah Pada Penderita Hipertensi}

Hasil analisis data penelitian menunjukkan bahwa ada perbedaan yang bermakna penurunan tekanan darah baik pada tekanan sistole maupun diastole antara kelompok perlakuan dengan kelompok kontrol. Hasil ini dapat disimpulkan bahwa pada kelompok yang diberikan air rebusan seledri lebih baik dalam menurunkan tekanan darah baik pada tekanan sistole maupun diastole. Hasil uji statistik (Mann Whitney $\mathrm{U}$ ) untuk tekanan darah sistole diperoleh p-value 0,047 dan untuk tekanan darah diastole diperoleh $\mathrm{p}$-value 0,015 atau nilai $\mathrm{p}<0.05$ yang artinya bahwa terdapat perbedaan yang bermakna tekanan darah sistolik dan diastolik pada kelompok perlakuan dan kelompok kontrol di Wilayah Kerja Puskesmas Pembantu Berngam Tahun 2021.

Penelitian ini sejalan dengan penelitian yang dilakukan Anugerah, dkk [1] dengan judul pengaruh pemberian rebusan daun seledri (Apium Graveolens L) terhadap tekanan darah pada wanita menopause dengan hipertensi. Hasil penelitian menunjukkan bahwa ada perubahan penurunan tekanan darah melalui pemberian rebusan daun seledri dengan selisih peurunan tekanan darah 28,47 mmHg. Pemberian rebusan daun seledri diberikan sebanyak 1 kali 1 hari tepatnya di sore hari pada interval waktu 14.00-16.00 WIB sebanyak $200 \mathrm{cc}$. Dengan mengkonsumsi 8 batang daun seledri selama 1 minggu dapat menurunkan tekanan darah menjadi $18.75 \%$ karena di dalam daun seledri banyak mengandung magnesium, ptalides, apingenin, kalium dan asparagin yang akan mengontrol pembuluh darah untuk berkontraksi dan relaksasi sehingga tidak terjadi penyempitan pada pembuluh darah serta membantu proses diuretik dan mengandung senyawa penenang berupa ptslides yang akan mengkontrol aktivitas pembuluh darah. 
Penelitian ini juga sesuai dengan penelitian Lazdia, dkk [6] bahwa Rerata tekanan darah sistolik sesudah mengonsumsi rebusan daun seledri adalah sebesar $136 \mathrm{mmHg}(\mathrm{SD}=10,750)$, lebih rendah daripada rerata tekanan darah sistolik sebelum mengonsumsi rebusan daun seledri, yakni sebesar $142 \mathrm{mmHg}(\mathrm{SD}=13,984)(\mathrm{p}>0,05)$. Rata-rata tekanan darah diastolik sesudah mengonsumsi rebusan daun seledri adalah sebesar $87 \mathrm{mmHg}(\mathrm{SD}=4,830)$, lebih rendah daripada rata-rata tekanan darah diastolik sebelum mengonsumsi rebusan daun seledri sebesar $94 \mathrm{mmHg}(\mathrm{SD}=9,661)(\mathrm{p}<0,05)$. Penelitian Suryarinilsih, dkk [7] menyatakan terdapat perbedaan yang bermakna terhadap penurunan tekanan darah pada pasien hipertensi pada lansia yang sudah diberi intervensi rebusan seledri. Hal ini disebabkan menurut teori karena kandungan vitamin $\mathrm{C}$ dalam seledri berperan penting melalui proses kolesterol, karena dalam proses metabolisme kolesterol, vitamin $\mathrm{C}$ dapat meningkatkan laju kolesterol yang dibuang dalam bentuk asam empedu dan mengatur metabolisme kolesterol.

Rebusan daun seledri dapat menurunkan umum seledri dalam mengontrol tekanan darah antara lain, memberikan efek dilatasi pada pembuluh darah dan menghambat angiotensin converting enzym (ACE). Penghambat sistem renin-angiotensin dapat menurunkan kemampuan ginjal dalam meningkatkan tekanan darah.Tekanan darah mulai turun sehari setelah pengobatan yang diiukti dengan membaiknya tidur terasa nyaman, dan jumlah urin yang dikeluarkan meningkat. Seledri mengandung flevonoid, saponi, tanin $1 \%$ minyak asiri $0,033 \%$, flavuglukosida (apiin), apigenin, fitosterol, kolin, lipase, pthalides, asparagine, zat pahit, vitamin (A, B dan C), apiin minyak menguap, apigenin dan alkaloid. Kandungan kimia daun seledri secara keseluruhan.Apigenin dalam daun seledri berfungsi sebagai beta blocker yang dapat memperlambat detak jantung dan menurunkan kekuatan kontraksi jantung sehingga aliran darah yang terpompa lebih sedikit dan tekanan darah menjadi berkurang [10].

Penelitian ini menjadi efektif menurunkan tekanan darah karena Apium graveolens atau seledri, digunakan dalam pengobatan tradisional sebagai agen anti hipertensi, mengandung senyawa kimia seperti apiin, apigenin, isoquercitrin, dan sesquiterpene [10]. Kandungan apigenin yang berperan sebagai antagonis kalsium memiliki efek vasodilatasi.Selain itu seledri mengandung nbutylphthalide (NBP) sebagai salah satu kandungan utama, yaitu senyawa berminyak dan tidak berwarna pada seledri. Kandungan minyakpada seledri memainkan peran penting dalam efek antihipertensi dari ramuan ini [11].

\section{Kesimpulan}

Hasil uji statistik (Mann Whitney $U$ ) untuk tekanan darah sistole diperoleh p-value 0,047 dan untuk tekanan darah diastole diperoleh p-value 0,015 atau nilai $\mathrm{p}<\alpha(0.05)$ yang artinya bahwa terdapat perbedaan yang bermakna tekanan darah sistolik dan diastolik pada kelompok perlakuan dan kelompok kontrol di Wilayah Kerja Puskesmas Pembantu Berngam Tahun 2021. Disarankan kepada para tenaga Kesehatan untuk dapat menerapkan dan mensosialisasikan terapi komplementer dengan memanfaatkan rebusan seledri kepada penderita hipertensi untuk menurunkan tekanan darah pada kasus hipertensi ringan.

\section{Sumber Pendanaan}

Direktorat Riset dan Pengabdian Masyarakat, Deputi Bidang Penguatan Riset dan Pengembangan Kementerian Riset dan Tehnologi, Badan Riset dan Inovasi Nasional yang telah memberikan dukungan keuangan untuk melakukan penelitian ini.

\section{Referensi}

[1] Bustan., M, N. Pengantar Epidemiologi, Jakarta : Rineka Cipta. 2006.

[2] Kementerian Kesehatan, RISKESDAS 2013, Jakarta Indonesia Anonim. 2014

[3] Kabo P. Mengungkap Pengobatan Penyakit Jantung Koroner, Jakarta ; Gramedia Pustaka Utama. 2008.

[4] Fauziah, Rifki. Cantik sehat dan awet muda dengan buah dan sayur, Yogyakarta. 2015.

[5] Muzakar, Nuryanto. Pengaruh Pemberian Air Rebusan Siledri Terhadap Penurunan Tekanan Darah Pada Penderita Hipertensi. Jurnal Pembangunan Manusia. Volume 6. No.1. 2012.

[6] Weny Lazdia, Widya Abdilatul Rahma. Pengaruh rebusan daun seledri untuk menurunkan tekanan darah pada penderita hipertensi e-ISSN : 2775-2403. 2020. 
[7] Fuziah, Rifka. Cantik Sehat dan Awet Muda Dengan Buah dan Sayur, Yogyakarta. 2015.

[8] Suryarinilsih, Yosi, Yesi Fadriyanti, Hidayatullah Hidayatullah. Rebusan Seledri Terhadap Penurunan Tekanan Darah Pasien Hipertensi, Jurnal Penelitian dan Kajian Ilmiah, Menara Ilmu Universitas Muhammadiyah Sumatera Utara, ISSN: 1693-2617, e-ISSN : 2528-7613. 2021.

[9] Sukahor A, \& Arisanda R. Seledri (Apium Graveolens) Sebagai Agen Kemopreventif Sebagai Kanker Majority, 5 (2), 95-96. 2016.

[10] Ningrum, Dinar R. Efektivitas Pemberian Jus Pisang Ambon Dan Rebusan Daun Seledri Untuk Menurunkan Tekanan Darah Pada Lansia Penderita Hipertensi Di Posyandu Dewi Kunti Kelurahan Winongo Kota Madiun Skripsi, Progam Studi Keperawatan Stikes Bhakti Husada Mulia Madiun. 2019.

[11] Pratiwi Putu Desak, Sutadarma Gede Iwayan. Hubungan Pola Konsumsi Seledri (Apium Graveolens L) terhadap Tekanan Darah Mahasiswa Fakultas Kedokteran Universitas Udayana. 2019. 